\title{
Commentary
}

Russell Sbriglia*

\section{Notes Toward an Extimate Materialism: A Reply to Graham Harman}

https://doi.org/10.1515/opphil-2020-0175

received July 20, 2021; accepted August 02, 2021

\begin{abstract}
This article mounts a defense of my and Slavoj Žižek's co-edited anthology, Subject Lessons: Hegel, Lacan, and the Future of Materialism, against the two main criticisms of it made throughout Graham Harman's article "The Battle of Objects and Subjects": (1) that we and our fellow contributors are guilty of gross overgeneralization when we classify thinkers from various schools of thought - among them New Materialism, object-oriented ontology, speculative realism, and actor-network theory - under the broad rubric of the "new materialisms"; and (2) that despite our pretensions to the mantle of materialism, our Lacano-Hegelian position is actually a full-blown idealism. In responding to and attempting to refute these criticisms, I make the case that our Lacano-Hegelian model of dialectical materialism is an "extimate materialism."
\end{abstract}

Keywords: Graham Harman, Slavoj Žižek, Ljubljana School, Jacques Lacan, G. W. F. Hegel, subjectivity, dialectical materialism, idealism, realism, objet petit a

I would like, here at the outset, to express my gratitude to Graham Harman for cordially inviting me to respond to his recent article, “The Battle of Objects and Subjects: Concerning Sbriglia and Žižek’s Subject Lessons Anthology," in which he not only defends his object-oriented ontology (000) from the critiques leveled against it throughout my and Žižek's anthology, but also critiques the Lacano-Hegelian model of dialectical materialism championed by the anthology's contributors. Seeing that Harman has limited his response to those chapters of the collection that most concern 000, in what follows I have tried my best to limit my response to Harman himself, though I will occasionally have cause to address critiques from compatriots of his such as Levi Bryant, Manuel DeLanda, and Quentin Meillassoux. ${ }^{1}$ Likewise, though I may now and then refer to Harman's comments on chapters by other contributors to the volume such as Nathan Gorelick, Adrian Johnston, Todd McGowan, and Molly Anne Rothenberg, my focus will remain primarily on Harman's response to my and Žižek's introductory chapter, which, as we shall see, is of a piece with other of the critiques he has leveled against Žižek and the Lacano-Hegelian position more generally in recent years.

1 Harman might disagree with the designation of Meillassoux as a "compatriot" of his. As he has done elsewhere, in his response to Subject Lessons Harman expresses puzzlement at our treating Meillassoux as "an opponent who gets things basically wrong, despite the fact that there is a tremendous degree of agreement between them.” This strikes me as an altogether fair assessment - though I would nonetheless stress that, as is clear from Meillassoux's and Žižek's critiques of each other's positions (which I will discuss below), our answers to the problem of correlationism are entirely different. Harman, "The Battle of Objects and Subjects,” 319.

\footnotetext{
* Corresponding author: Russell Sbriglia, Department of English, Seton Hall University, South Orange, United States of America, e-mail: russell.sbriglia@shu.edu
} 
I should make it clear at the outset of this reply that those coming to it expecting to find a polemic will be sorely disappointed. Both the current piece and that to which it responds constitute merely the most recent installment in an ongoing friendly debate between Harman and various members of the LacanoHegelian camp whose work is featured in Subject Lessons. ${ }^{2}$ I should also make it clear that I am not interested in using this reply to wage a further critique of OOO, as I am happy to let what Žižek and I wrote in regard to it in the introduction to our collection stand on its own. What I am interested in doing is looking closely at and responding to Harman's main critiques of our collection - not in the hope of ultimately converting him to our cause or convincing him of the correctness of our position (like Žižek, I have "no illusions" in this regard), but in the hope that doing so will help to provide greater clarity, not only about some of the seemingly contradictory claims undergirding our Lacano-Hegelian model of dialectical materialism - especially regarding the nature of the Lacanian "objet petit $a$," the matter that matters most to this materialism - but also about where the true fault line between this "extimate materialism," as I will be terming it, and Harman's "immaterialism" lies. ${ }^{3}$

Though it contains more granular critiques than these - especially when addressing those chapters of the book that engage $\mathrm{OOO}$ at the greatest length (Johnston's, McGowan's, and Rothenberg's) - the two most overarching critiques throughout Harman's response to Subject Lessons are the following: (1) we and our fellow contributors are guilty of gross overgeneralization when we classify thinkers from various schools of thought - among them New Materialism, 000, speculative realism, and actor-network theory (ANT) - under the broad rubric of the "new materialisms"; and (2) despite our pretensions to the mantle of materialism, our Lacano-Hegelian position is actually a full-blown idealism. I will address these critiques in order, beginning with the first; however, I will devote a good deal more space to the second, as there is far more at stake philosophically in this critique than in the first, which is more methodological in nature.

\section{A dangerous method?}

As outlined above, one of Harman's more overarching complaints throughout his response to Subject Lessons is that we-specifically Žižek and I, but also some others in the collection, such as McGowan, Gorelick, and Alenka Zupančič - are "generally too indiscriminate in mixing various figures under the 'New Materialist' label, often suppressing crucial differences." ${ }^{4}$ I am tempted to both agree and disagree with Harman here. As far as agreement goes, Harman is correct to note that such a "bulk treatment" of figures like himself and Levi Bryant (both of whom are object-oriented ontologists), Jane Bennett (a New Materialist), Quentin Meillassoux (a speculative materialist), and Bruno Latour (an actor-network theorist) cannot but help to "suppress" some of the more "crucial differences" among them. ${ }^{5}$ To take Harman himself as an example, it is entirely understandable that he wouldn't want to be lumped in with the New Materialists, if for no other reason than that his 000, as he has argued on a number of occasions, is an "immaterialism." Indeed, in his book Immaterialism Harman explicitly distinguishes between the

2 As Johnston notes at the outset of his chapter in Subject Lessons, "Fear of Science," he and Harman have debated each other on a number of occasions, both in person and in print. Likewise, Žižek and Harman, in addition to engaging each other's work in a number of their texts, have debated each other twice in person: the first time on March 1, 2017, in what was billed as a "Duel + Duet" at the Southern California Institute of Architecture (SCI-Arc), and the second time on December 1, 2018, at the Munich School of Philosophy as part of a conference dedicated to the concept of "parallax." Video recordings of both events can be easily found on YouTube.

3 My approach here follows that of Žižek, who began his remarks during his "Duel + Duet” with Harman by not only clarifying that he had "no illusions" that he and Harman would arrive at some sort of deep agreement with one another, but also stressing that "it would be a great success if we just somehow clarif[ied] where the difference [between our two philosophical positions] really is," for "the biggest problem in so-called philosophical dialogues [is] not who is right, but in what does the difference reside in the first place."

4 Harman, "The Battle of Objects and Subjects," 314.

5 Ibid. 
immaterialism of his $\mathrm{OOO}$ and the materialism of New Materialism by way of contrasting lists of "axioms" of both schools. ${ }^{6}$ Thus, to give a few examples, whereas New Materialism holds that "[e]verything is contingent," that "[t]hought and the world never exist separately, and therefore 'intra-act' rather than interact," and that "[t]he world is purely immanent, and it's a good thing, because any transcendence would be oppressive," OOO holds that "[n]ot everything is contingent," that " $[\mathrm{t}]$ hought and its object are no more and no less than any other two objects, and therefore they interact rather than 'intra-act,"” and that "[t]he world is not just immanent, and it's a good thing, because pure immanence would be oppressive." Given that Harman has gone out of his way to draw such distinctions as these, one can understand why he would bristle at seeing his $\mathrm{OOO}$ being grouped alongside New Materialism. And yet, as we will see, not only is this not an entirely accurate characterization of my and Žižek's classification of these various schools of thought, but there is also considerable disagreement - even confusion - among these schools' own members as to whether their philosophy is a materialism, a realism, or both.

In his response to Subject Lessons, Harman reiterates his anti-materialist stance by citing articles of his boasting such titles as "I Am Also of the Opinion That Materialism Must Be Destroyed," "Realism Without Materialism," and "Materialism Is Not the Solution." Surely, the title of the second of these three articles, "Realism Without Materialism," would justify us in classifying Harman's 000 as a "new realism" - especially given that, as I will address below, he explicitly rejects classic, "naïve" realism. This brings me to the first of my objections to Harman's criticism of our bulk treatment of these different schools: in our introduction, Žižek and I very explicitly - and very consistently - refer to them not merely as the "new materialisms" (which is itself somewhat more capacious a term than the proper noun "New Materialism"), but as the "new materialisms and realisms." Curiously, Harman doesn't acknowledge this in his response (though he does quote our claim that, "from the Lacano-Hegelian perspective, what new materialists and realists understand as 'subject' simply fails to meet the criteria of the subject"). ${ }^{10}$ Instead, he takes Gorelick's grouping of these different schools under the rubric of "new materialism" in his chapter "Why Sex Is Special: Psychoanalysis against New Materialism" as though it were indicative of the volume as a whole. But let us for a moment assume that this was indeed true of the book more generally. Given the amount of disagreement that exists among the members of these various schools - even those belonging to the same school - not only as to whether their philosophies are materialist or realist, but even as to what "materialism" and "realism" mean, one could hardly blame other of the book's contributors for following Gorelick's example in resisting "the nominalist temptation to arbitrate such nuances," especially seeing that such arbitration is "already a common preoccupation among these thinkers themselves." 11

6 Harman, Immaterialism, 14-6.

7 Ibid. Not only has Harman worked to differentiate 000 from New Materialism, but so too have New Materialists worked to differentiate New Materialism from 000. See, for instance, Jane Bennett, “Systems and Things”; and Rebekah Sheldon, "Form/ Matter/Chora."

8 Harman, "The Battle of Objects and Subjects," 315.

9 The phrase "new materialisms and realisms" and cognates such as "new materialists and realists" occur nearly twenty times throughout our introduction. In addition to his efforts to distinguish 000's realism from naïve realism, I would also point out that Harman wrote the foreword to the English translation of Maurizio Ferraris's Manifesto of New Realism, which leads me to believe that he wouldn't (or shouldn't) object to the classification of $\mathrm{OOO}$ as a "new realism." What I could see him objecting to (although he doesn't address this in his response) is the categorization of 000 as a "neovitalism" (another umbrella term that we use throughout our introduction to refer to these various schools), though he does cite Whitehead (if not Deleuze) as an influence.

10 Sbriglia and Žižek, "Introduction,” 14-5, emphasis added; Harman, “The Battle of Objects and Subjects," 317-8.

11 Gorelick, "Why Sex Is Special," 187n1. Worth noting here is that Gorelick does indeed concede that there are "obviously many differences internal to these general categories," adding that "several of the thinkers with whom we are contending likely would be uneasy about their inclusion under the heading of "new materialism." Furthermore, though Harman, in addressing Gorelick, is correct to point out that whereas his 000 is a "philosophy of full-blown objects," Jane Bennett's New Materialism is a philosophy of a "single matter-energy," this difference does little to invalidate Gorelick's claim that the two schools share a "common foundation" of attempting to "retriev[e] the question of the object from the conception of the transcendental subject" (Ibid.). Harman, “The Battle of Objects and Subjects,” 315. 
To indulge in a bit of this arbitration myself, we might note that though often considered the ur-text of speculative realism, Quentin Meillassoux's After Finitude is, in Meillassoux's own estimation, a work of "speculative materialism." 12 As he asserts in his essay "Time Without Becoming," "I prefer to describe my philosophy as a speculative materialism, rather than as a realism: because I remember the sentence of Foucault, who once said: 'I am materialist, because I don't believe in reality."'13 A similar tension exists within 000. Whereas Harman's position, as we have seen, is staunchly anti-materialist, that of his fellow object-oriented ontologist Levi Bryant is staunchly materialist. To exemplify this point, one need look no further than the very first sentence of Bryant's Onto-Cartography, in which he proclaims, "This book attempts a defense and renewal of materialism" - both of which, he adds, are needed "in the face of critics and defenders alike." ${ }^{4}$ To take up this last point regarding defenders of materialism: in a passage that Harman often approvingly cites - including in his response to Subject Lessons - Bryant singles out Žižek's work in particular as evidence that the word "materialism" has become an "empty" signifier, a mere "terme d'art which has little to do with anything material." 15 I will quote and discuss this passage from Bryant at much greater length below. For now, suffice it to note that his aim of "defending and renewing" materialism speaks to a fundamental disagreement among the two most prominent practitioners of $\mathrm{OOO}$ as to whether it is (or should be) a materialist or an immaterialist philosophy. ${ }^{16}$

Complicating matters even further are disagreements and contradictions among these thinkers as to their very definitions of "materialism" and "realism." As suggested earlier, by "realism" Harman means not a commonsense philosophy that insists upon the existence of material objects outside of human perception - a position whose naiveté is perhaps most famously (and colorfully) encapsulated by Samuel Johnson's response to Berkeley's idealism by kicking a large stone and proclaiming, "I refute it thus" - but rather a philosophy that "reject[s] the central teaching of Kant's Copernican Revolution, which turns philosophy into a meditation on human finitude and forbids it from discussing reality in itself." ${ }^{17}$ While such a definition of realism could in certain respects double as a characterization of Meillassoux's anticorrelationism, Meillassoux, as we have seen, rejects the label of realism, a move that would get him into trouble not only with Harman but with another figure in this orbit, Manuel DeLanda. ${ }^{18}$ Responsible for having popularized the notion of "flat ontology" to which virtually all of the new materialists and realists that we discuss in our collection subscribe, DeLanda is, in Harman's estimation, "both ardently realist and

12 The term "speculative materialism" occurs twice throughout After Finitude (38, 121), while "speculative realism" is entirely absent from it. In his introduction to Towards Speculative Realism, Harman acknowledges that, rather than representing a "unified school," speculative realism is a "loose umbrella term" that encompasses "four markedly different," even "incompatible,” positions: Meillassoux's speculative materialism, Ray Brassier’s eliminative nihilism, Iain Hamilton Grant's cyber-vitalism, and Harman's own object-oriented philosophy. Harman, Towards Speculative Realism, 1.

13 Meillassoux, Time Without Becoming, 19. Harman would likely cite this line as a key instance of why he believes Meillassoux is closer to our position than his own, as Meillassoux here seems to echo what, for Harman, is one of Žižek's most infamous assertions (made during an interview with Glyn Daly): "the only consistent materialist position is that the world does not exist - in the Kantian sense of the term, as a self-enclosed whole.” Then again, in an interview with Harman, Meillassoux rejects the notion that he "do[es] not 'believe' in an objective world independent of thought," maintaining that he not only "'know[s]' that there is such a world," but that such knowledge is precisely "what makes [him] a materialist." One way of attempting to square these seemingly contradictory statements of Meillassoux's would be to posit that, in addition to distinguishing between knowledge and belief, he is also distinguishing between "reality" and "an objective world independent of thought." Žižek and Daly, Conversations with Žižek, 97; Meillassoux in Harman, Quentin Meillassoux, 168.

14 Bryant, Onto-Cartography, 1.

15 Ibid., 2.

16 A further indication of such internecine distinctions is that Harman frequently finds himself having to add qualifiers when criticizing our "bulk treatment" of these various schools. The following line is illustrative of this pattern: "Whereas Zupančič argues that Deleuze is the shared root of all three trends, that is really only true of New Materialism, and not of OOO (other than Levi Bryant) or Speculative Realism (other than Iain Hamilton Grant).” Harman, "The Battle of Objects and Subjects," 315; emphasis added.

17 Boswell, Life of Johnson, 333; Harman, Towards Speculative Realism, 2.

18 One important distinction to draw here is that though Meillassoux, like Harman, has a negative view of Kant's Copernican Revolution, dubbing it in After Finitude the "Kantian catastrophe" (124), he nonetheless insists that we cannot simply bypass the correlationist problematic altogether (as Harman attempts to do) but must, rather, refute it from within. 
ardently materialist." ${ }^{19}$ As DeLanda himself asserts in his extended dialogue with Harman, The Rise of Realism - this after having confessed to 'using the terms 'realism' and 'materialism' as if they were interchangeable when they are not" - "All (coherent) materialists must be realists, but not all realists must be materialists.”20 From here, however, DeLanda, though critical of Žižek’s materialism (a critique which, like Bryant's, I will address in greater detail below), proceeds to provide a definition of materialism which, were one to simply remove the term "realism" from it, would be entirely applicable to my and Žižek's LacanoHegelian position: "a form of realism that rejects any entity that transcends the material world."21 Going by this definition, if ours is "a bad form of materialism," then so too is DeLanda's. ${ }^{22}$

To reiterate, then: my response to Harman's criticism of our "bulk treatment" of these various thinkers and schools is a simultaneous plea of "Guilty!" and "Not guilty!” While I can certainly appreciate his wanting us to have paid more attention to the differences both between and within 000, New Materialism, speculative materialism, and ANT, I would nonetheless continue to insist that such differences do nothing to detract from the fact that all four of these schools share an overarching commitment to establishing a flat, horizontal ontology - a horizontology, if you will - the upshot of which is the decentering and demotion of the subject. ${ }^{23}$ For this reason alone - especially seeing that, as its title suggests, Subject Lessons is a book dedicated to defending the subject against such decenterings and demotions - I stand by our grouping of these various schools under the rubric of "new materialisms and realisms."

\section{Did somebody say materialism?}

Harman's second major accusation - that despite our pretensions to the mantle of materialism, our LacanoHegelian position is actually a fully blown idealism - is not merely of greater interest to me, but, as I have already suggested, of greater philosophical concern as well. Before directly addressing the charge of idealism, however, I would like to first consider Harman's critique of our materialism, since it is the latter that paves the way for the former.

Though an avowed anti-materialist (as we have established), Harman has on numerous occasions criticized the Lacano-Hegelian position (Žižek's articulation of it especially) for its failure to be truly materialist. As he has done elsewhere, Harman frames his critique of the position laid out in Subject Lessons by way of the following, aforementioned passage from Levi Bryant's Onto-Cartography, in which Bryant cites Žižek's work as a prime example of the putative "emptiness" of contemporary materialism:

The term materialism became so empty that Žižek could write, "[m]aterialism means that the reality I see is never 'whole' - not because a large part of it eludes me, but because it contains a stain, a blind spot, which indicates my inclusion in it." This is a peculiar proposition indeed. What need does matter have to be witnessed by anyone? What does a blind spot have to do with matter? Why is there no talk here of "stuff," "physicality," or material agencies? It would seem that among the defenders, materialism has become a terme d'art which has little to do with anything material. Materialism has come to mean simply that something is historical, socially constructed, involves cultural practices, and is contingent. It has nothing to do with processes that take place in the heart of stars, suffering from cancer, or transforming fossil fuels into greenhouse gases. We wonder where the materialism in materialism is. ${ }^{24}$

19 Harman, in DeLanda and Harman, The Rise of Realism, 3. DeLanda first expounded upon the notion of "flat ontology" in his book Intensive Science and Virtual Philosophy.

20 DeLanda, in DeLanda and Harman, The Rise of Realism, 4.

21 Ibid., 4-5.

22 Ibid., 8. To be precise, it is Marxism in general that DeLanda characterizes as "a bad form of materialism”; however, seeing that he uses Žižek as his main example of a Marxist materialist, I see no issue with the small license I have taken here.

23 Here I would note that the notion of "horizontalizing" the ontological plane is derived from Bruno Latour, whose ANT is an indisputable influence on both 000 and New Materialism.

24 Bryant, Onto-Cartography, 2. The Žižek quote, which I will come back to later, is from his book The Parallax View, 17. For other instances of Harman citing this passage from Bryant - often as a means of calling into question Žižek's materialism - see his Immaterialism, 13; Object-Oriented Ontology, 135; and, with DeLanda, The Rise of Realism, 9. 
We will have cause to address Bryant's critique of Žižek in its own right later. For now, suffice it to note that Harman uses this passage as a means of teeing up his point that it is "by no means clear" where the materialism is in our claim that "from the dialectical materialist standpoint, the true formula of materialism is that material reality is non-all." 25

As Harman explains in his Object-Oriented Ontology, “Traditional materialism was the idea that nothing exists other than tiny physical particles speeding through a void. Everything else that seemed to exist was to be reduced to such particles, and everything immaterial was to be mocked ruthlessly on this basis." ${ }^{26}$ This is the sort of materialism with which Bryant explicitly aligns his "unabashedly naïve" materialism - a materialism which attends to the "'stuff' and 'things"” that compose the physical world, from "trees, rocks, planets, stars, wombats, and automobiles" to "various forms of energy, strings, fundamental particles, and so on." ${ }^{27}$ To be clear, I am entirely sympathetic to the "meta-politic[al] and meta-ethic[al]" aims of Bryant's "onto-cartographic" materialism. After all, how could any self-respecting leftist not be interested in "expand[ing] our possibilities for intervening in the world to produce change so as to better understand how power functions and devise strategies so as to overcome various forms of oppression"?28 However, to claim, as Bryant and Harman do, that Lacano-Hegelian dialectical materialism is not really materialist because it doesn't subscribe to the same tradition of naïve materialism as Bryant's onto-cartography strikes me as not only rather peculiar (would Žižek and I be justified in claiming that Harman's object-oriented ontology isn't truly realist because it doesn't subscribe to the naïve realism of Samuel Johnson or Scottish common sense philosophers like Thomas Reid and James Beattie?), but also simply incorrect.

Though it doesn't come up in his response to Subject Lessons, a common accusation of Harman's is that Žižek clings to the moniker "materialism" primarily as a means of demonstrating his leftist bona fides. For instance, in his aforementioned dialogue with DeLanda, Harman, having claimed that Žižek isn't "the least bit materialist," goes on to suggest that the reason he continues to call himself such is that he "want[s] to link [himself] to the Left/Enlightenment political prestige of the term." ${ }^{29}$ Nodding in agreement, DeLanda not only dismisses the "old Left" as an "exhausted," "embarrassing," and "increasingly irrelevant tradition," but, more importantly, accuses Žižek of having contributed to "the debasement of the term "materialism"” by using it "as short for either 'dialectical materialism' or 'historical materialism,"” "as if Marxists had a monopoly on materialist ideas." ${ }^{30}$ Leaving aside DeLanda's labeling of Žižek's dialectical materialism as Marxian when, for over 30 years now, he has repeatedly gone out of his way to stress that it is Hegelian contra Marxian, ${ }^{31}$ the implication that Žižek is continuing to wave the banner of materialism primarily for the political prestige it carries on the Left overlooks the many links between his dialectical materialism and the very "traditional materialism" to which Harman (like Bryant) accuses it of bearing no relation. ${ }^{32}$

25 Harman, “The Battle of Objects and Subjects," 319; Sbriglia and Žižek, "Introduction," 9.

26 Harman, Object-Oriented Ontology, 135. Harman provides a similar definition of traditional materialism in his dialogue with DeLanda: “Materialism' in its original form meant a reduction that explained things away in terms of some ultimate physical element or particle. This was true of the pre-Socratics, many Enlightenment thinkers, and even twentieth-century scientists such as Ernest Rutherford, who admitted to imagining atoms as hard red billiard balls.” Harman, in DeLanda and Harman, The Rise of Realism, 9.

27 Bryant, Onto-Cartography, 6.

28 Ibid., 8.

29 Harman, in DeLanda and Harman, The Rise of Realism, 9. Though he doesn’t single Žižek out in this instance, Harman makes much the same point in his Immaterialism when, lamenting that materialism is "one of the most overly cherished words in present-day intellectual life," he goes on to assert that "much of the prestige of this term stems from its long association with the Enlightenment and the political Left" (13).

30 DeLanda, in Harman and DeLanda, The Rise of Realism, 10, 5, 10, 5, 9.

31 Perhaps Žižek's most iconic articulation of this point comes in his book Tarrying with the Negative, wherein he asserts that, 'after more than a century of polemics on the Marxist 'materialist reversal of Hegel,' the time has come to raise the inverse possibility of a Hegelian critique of Marx.” Žižek, Tarrying with the Negative, 26.

32 Bryant suggests that the difference between his materialism and the "empty" materialism of which he takes Žižek to be a prime example can be attributed to a "difference in intellectual historical lineages": whereas his onto-cartographic materialism is “descended from the Greek atomist Democritus,” Žižek's materialism "hail[s] from historical materialism.” Yet, not only does Žižek’s dialectical materialism not hail from historical materialism, but, as the following paragraph demonstrates, it is indeed 
Let us return to Harman's query regarding where, exactly, the materialism lies in our claim that "from the dialectical materialist standpoint, the true formula of materialism is that material reality is non-all." As Žižek and I explain in our introduction to Subject Lessons, the formula "material reality is non-all" is Lacanese for asserting that material reality is "ontologically incomplete," "inconsistent," "thwarted," contradictory. ${ }^{33}$ Though Harman claims that the link between "such language of the "non-all"” and materialism "is by no means clear," it becomes quite clear if one looks more closely at the tradition of dialectical materialism whose torch he accuses us of carrying merely as a means of brandishing our leftist credentials. ${ }^{34}$ In addition to Mladen Dolar's and Andrew Cole's chapters in Subject Lessons, I would refer readers to the recently-published second volume of Adrian Johnston's Prolegomena to Any Future Materialism - A Weak Nature Alone - which covers much of this ground in painstaking detail and depth. For our present purposes, suffice it to stress that our understanding of materialism as "non-all" can be traced back not only to "modern" dialectical materialists, from Hegel, Marx, and Engels in the nineteenth century to Lenin, Mao, and Lacan in the twentieth, but also to ancient materialists like Heraclitus, Democritus, Epicurus, and Lucretius. ${ }^{35}$ Let us not forget that Hegel, Engels, Lenin, and Mao all esteemed Heraclitus the father not only of the dialectic, but of dialectical materialism. ${ }^{36}$ Let us also not forget that Marx wrote his doctoral thesis on "The Difference Between the Democritean and Epicurean Philosophies of Nature," a text in which, as Dolar notes, Marx "pinned the fate of materialism" on the great Epicurean archetype of contingency, "clinamen," the swerve of atoms from their linear path. ${ }^{37}$ Nor, finally, let us forget that not only did Lacan link the death drive, the "negative' libido" that opens up "the dimension of a vital dehiscence constitutive of man," to "the Heraclitean notion of Discord - which the Ephesian held to be prior to harmony," but that he also cited both the Epicurean clinamen and the Democritean "den" (the "less than nothing”) as precursors of the psychoanalytic object par excellence (that object which Lacan claimed was his only invention), the objet petit $a$, the object-cause of desire. ${ }^{38}$ Examples such as these would suggest that our continued use of the term "materialism" is far from a mere exercise in political branding.

descended from the atomism of the ancient materialists. In short, such a dichotomy doesn't hold up. Bryant, Onto-Cartography, 2.

33 Sbriglia and Žižek, "Introduction," 9-10. Lacan first introduces the notion of the "non-all” (pas-tout) when, in his twentieth seminar, Encore, he debuts his formulas of "sexuation," aligning the "non-all" with the "feminine" logic of the exception that resists the "phallic function" and, thus, full integration into the Symbolic. Hence Žižek’s frequent insistence that "woman" is the subject par excellence while masculinity is always a fake.

34 Harman, "The Battle of Objects and Subjects," 319.

35 Indeed, as Dolar stresses in his chapter for Subject Lessons, "What's the Matter?," modern and ancient materialism are joined at the hip insofar as "materialism" is "a modern term which then had to invent its own retroactive history, stretching back to the ancient atomism of Democritus and Epicurus, or even to the very beginning of philosophy, the first Greek naturalists, who strived for an immanent explanation of nature as opposed to mythos, demoting gods and mythology and relying on the natural sciences of the time." Hence Dolar's conclusion that "materialism has always already existed" (33), with the "always already" intended to connote that there is no ancient or traditional materialism outside of modern materialism.

36 In his History of Philosophy, Hegel not only deems philosophy to have truly begun with Heraclitus (as he colorfully puts it, "Here we see land"), but also famously proclaims that "there is no proposition of Heraclitus which I have not adopted in my Logic" - a remark that holds true of the shorter and longer Logics alike. Engels, in both his Anti-Dühring and Socialism: Utopian and Scientific, esteems Heraclitus's theory that "everything is and is not, for everything is fluid, is constantly changing, constantly coming into being and passing away," a "primitive, naïve but intrinsically correct conception of the world" - these remarks coming on the heels of having praised Hegel for his "taking up again of dialectics" from "[t]he old Greek philosophers [who] were all born natural dialecticians." Lenin's remarks on Heraclitus can be found in his Philosophical Notebooks, in his conspectus on Ferdinand Lassalle's The Philosophy of Heraclitus the Obscure of Ephesus, wherein he asserts that Heraclitus's philosophy of perpetual flux provides a "very good exposition of the principles of dialectical materialism." Finally, Mao, in his commentary on Li Da's Outline of Sociology, remarks that Heraclitus's "great achievement was the discovery of the outline of materialist dialectics," a discovery brought about by his having identified "the two basic dialectical ideas: that all things are constantly changing, and change is the result of internal contradiction," "the inner struggle of opposites." Hegel, History of Philosophy, 279; Marx and Engels, The Marx-Engels Reader, 694; Lenin, Collected Works, 349; Zedong, “Annotations,” 817-8. 37 Dolar, “Tyche, clinamen, den," 231.

38 Lacan, Écrits, 94; The Four Fundamental Concepts of Psychoanalysis, 63-4. As Dolar notes, Lacan followed Marx in viewing these ancient concepts as "concomitant with the very possibility of materialism.” Dolar, "What's the Matter?,” 41. For extended 


\section{Did somebody say idealism?}

My having (finally) mentioned Lacan's objet petit a brings us, at long last, to Harman's claim that throughout Subject Lessons "'materialism' is used as an alibi to advance a thoroughly idealist position while claiming to be immune to the usual defects of idealism." ${ }^{39}$ What makes such a position ineluctably idealist, according to Harman, is that the objet $a$, the miserable little piece of the Real, the traumatic kernel that resists symbolization (and thus integration into the Symbolic), "does not come from the outside in any rigorous sense of the term," but is merely (and this is a wonderful turn of phrase) "a flaw in the jewel of consciousness." 40 As the ensign of a Real that "has little reality about it" insofar as it "stands not for some sort of real world outside the mind, but for an immanent trauma in consciousness itself," the objet $a$, whatever Lacan's claim that his "discourse" is a dialectical materialist one, renders his teaching, perforce, an "extreme idealis[m]." ${ }^{41}$ For Harman, this holds true even when Lacanians like Žižek and I attempt to "finesse [ourselves] out of this jam" by calling attention not only to the reciprocity between the subject and objet $a$, but also to the way in which the objet $a$ interpellates - or, more precisely, hystericizes - the subject.

Take, for instance, Harman's recent discussion of Rosalind Krauss's invocation of the famous "floating sardine can" anecdote from Lacan's eleventh seminar, The Four Fundamental Concepts of Psychoanalysis, in which Lacan explains his theory of the "gaze" (regard) as the look which an object casts at the subject rather than the typical vice versa of the subject looking at an object. ${ }^{42}$ In Harman's view, while this inversion may very well "suggest a novel equality between subject and object," ultimately

no reciprocity of this kind is ever enough to escape idealism, since human and world are still the only two terms allowed in the picture; above all, there is no talk of objects looking at each other, meaning that a human subject must always be somewhere on the scene. Thus, we are still inside the Kantian formalism that was supposedly just overcome [...]. [T]he inversion of the human being from an active conscious agent into a passive receiver of something from elsewhere does nothing to escape idealism, as long as humans and non-humans remain the only two pieces of the puzzle. ${ }^{43}$

For Harman, then, "placing 'the gaze' in the world itself rather than in a mind" and "proclaiming that the world looks at me just as I look at it" is neither a "genuine philosophical innovation" nor a genuine escape from correlationism. ${ }^{44}$ So long as we remain within the "onto-taxonomical" subject-object dyad, it matters not if we attribute equal or greater agency to the object: failing to address "object-object relations" means that our so-called materialism will always already be "spoil[ed]" by the same "central idealist defect." 45

discussions of Lacan on clinamen and den, see Dolar, “Tyche, clinamen, den,” and chapter nine of Žižek, Absolute Recoil, "From Here to Den.” For a more general discussion of Lacan and Heraclitus, see Badiou, "Lacan and the Pre-Socratics."

39 Harman, "The Battle of Objects and Subjects," 320.

40 Ibid., 326; Art and Objects, 129.

41 Harman, in DeLanda and Harman, The Rise of Realism, 6; Art and Objects, 129. In his eighteenth seminar, Lacan explicitly identifies his "discourse" as a dialectical materialist one, stressing, "If there is something I am, it is clear that I am not a nominalist [...]. If one is a nominalist, one has to renounce completely dialectical materialism, so that, all in all, I evidently reject the nominalist tradition which is effectively the only danger of idealism which can arise in a discourse like mine.” Lacan, D’un discours qui ne serait pas du semblant, 28; Žižek's translation, in Less Than Nothing, 780.

42 The passage of Krauss's to which Harman alludes is from her book The Optical Unconscious, 165. Lacan's sardine can anecdote occurs in the eighth lesson of Seminar XI, "The Line and Light." Also important to note here is that, though a privileged one, the gaze is for Lacan merely one manifestation of the objet $a$, the others being "voice," "breast," "phallus," and "feces."

43 Harman, Art and Objects, 129-30.

44 Ibid., 167.

45 Harman, "The Battle of Objects and Subjects," 328; Art and Objects, 167. In a way, Harman's critique of our supposed idealism is really a critique of our (again supposed) "onto-taxonomy," by which he means the "taxonomical prejudice which assumes in advance that the world must be divided up between a small number of radically different types of entities," most often the "implausible taxonomy between human thought on one side and everything else in the universe on the other," the result of this taxonomy being that humans have erroneously come to occupy "fifty per cent of ontology." Hence Harman's desire to move beyond the subject-object dyad to consider object-object relations. Harman, Object-Oriented Ontology, 256, 56. 
Harman is not alone in holding such a view of our Lacanianism - a point of which he is well aware. In an interview conducted by Harman, Meillassoux likewise accuses Žižek's materialism of being a "disingenuous idealism" insofar as it is (in his estimation) merely a "misfired" or "sickened" correlationism. Though lengthy, Meillassoux’s remarks are worth quoting in full:

[The position] of Žižek [...] consist[s] at bottom in making of materialism a "misfired correlationism.” Ever since Derrida in particular, materialism seems to have taken the form of a "sickened correlationism"; it refuses both the return to a naïve pre-critical stage of thought and any investigation of what prevents the "circle of the subject" from harmoniously closing in on itself. Whether it be the Freudian unconscious, Marxist ideology, Derridean dissemination, the undecidability of the event, the Lacanian Real considered as the impossible, etc., these are all supposed to detect the trace of an impossible coincidence of the subject with itself, and thus of an extra-correlational residue in which one could localize a "materialist moment" of thought. But in fact, such misfires are only further correlations among others: it is always for a subject that there is an undecidable event or a failure of signification. Unless we fall back on naïve realism, we cannot treat these misfires as "effects" of a cause that could definitely be established as external to the subject or even to consciousness. In any case, a correlationist would have no difficulty in retorting that this genre of materialism is either a disingenuous idealism or a dogmatic realism of the "old style." When a chair is wobbly, the "wobbly" exists only in relation to the chair, not independently of it. When one clogs up the Subject, one does not go outside it: instead, one merely constructs a transcendental or speculative Wobbly Subject - a subject that is assured a priori, and according to a properly absolute Knowing, for which things always turn out badly in its world of representations. ${ }^{46}$

Though not a realist (as we have seen), Meillassoux here makes all the same arguments as Harman. Shifting the locus of subjectivity from consciousness to the unconscious does nothing to break us out of the correlationist circle (the "Kantian formalism," as Harman puts it), for however "wobbly" such a subject of the unconscious may be, it remains a transcendental subject all the same, a subject for whom knowledge, precisely insofar as it is "assured a priori" (i.e., rationally constituted), is absolute. ${ }^{47}$ Such being the case, the objet $a$ whose materialization is an "effect" of this wobbliness, this "impossible coincidence of the subject with itself," though it may very well be a little piece of the Real, is ultimately not a real outside, not a genuine "extra-correlational residue" that would usher us into what Meillassoux, in his After Finitude, refers to as "the great outdoors," "the absolute outside of pre-critical thinkers." 48

Žižek has responded to this critique of Meillassoux's on two occasions, both of which can also be taken as rejoinders to Harman avant la lettre.$^{49}$ I will here focus on the more extended of these two responses, which occurs in his book Less Than Nothing..$^{50}$ Having identified the thrust of Meillassoux's (and, as we have seen, Harman's) argument to be the accusation that "beneath the rhetorical materialist surface, there lies good old-fashioned idealism,” Žižek begins his reply as follows:

On the face of it, the argument is convincing: do I not claim that, beneath the transcendental correlation between (the conscious) subject and reality, there is the correlative between the subject (of the unconscious) and its Real/impossible objectal counterpoint, S- $a$ ? Strange as this correlation is, it still makes sense only if a subject is already there, that is, it does not enable us to think reality without a subject. But, again, is this truly the case? The point Meillassoux misses is that this impossible/Real object is the very mode of inscription of the subject into trans-subjective reality; as such, it is not transcendental, but (what Derrida would have called) arche-transcendental, an attempt to circumscribe the "subject in becoming," the trans-subjective process of the emergence of the subject. ${ }^{51}$

46 Meillassoux in Harman, Quentin Meillassoux, 166.

47 Of course, for Meillassoux this is anything but actual absolute knowledge. As he is at pains to stress, the transcendental model of correlationism (of which he accuses Žižek's materialism of being a "sickened” or "misfired” version) entails "a denial of an absolute knowledge - I mean a knowledge of the thing in itself independently of our subjective access to it." Meillassoux, Time Without Becoming, 10.

48 Meillassoux, After Finitude, 7.

49 Žižek’s most sustained engagement with Harman’s 000 comes in his chapter of the book Reading Marx, "Marx Reads Object-Oriented Ontology.” His second most sustained engagement with 000 - one that is not only more critical, but that also focuses on Bryant rather than Harman - is the second chapter of his book Disparities, "Objects, Objects... and the Subject." 50 For Žižek's other response to this passage of Meillassoux's, see his Disparities, 102-3.

51 Žižek, Less Than Nothing, 642. 
To translate from Derridean to Lacanese, the subject of the unconscious is not a priori but objet a priori, by which pun I mean that it is not the subject that grounds the objet $a$, but the objet a that "grounds" the subject, that "gives body to," that "positivizes," the void that is the subject. The objet $a$ is the subject's "only substance," the "only positive support" of its being..$^{52}$ As such, it is not a question of what this impossible/ Real object is "for a subject," as Meillassoux (and Harman) want to frame things, but rather a question of what, for this object, is the subject. This hysterical question, "What for an object am I (in the eyes of the Other, for the Other's desire)?," is the inaugural gesture of subjectivity. ${ }^{53}$ Hence the Lacanian maxim, "the desire of the subject is the desire of the Other." Indeed, one can only speak of a "subject" (in the strong, psychoanalytic sense of the term) insofar as a "radical perplexity persists as to the Other's desire, as to what the Other sees (and finds worthy of desire) in me." ${ }^{4} 4$ The objet $a$ is thus not an answer to the question of the subject's desire; on the contrary, the subject is the "answer" to the question provoked by the enigma of the Other's desire, the question that Lacan famously identified as the "Chè vuoi?": "What does the Other want from me?" "What am I for the Other?" "Why am I what the Other says I am?"55

(Of course, we should also stress here that the Other is likewise desiring/lacking - hence another maxim of Lacan's, "the big Other does not exist" - which is why, contra Harman's accusation, Lacanian psychoanalysis does, in fact, attend to "object-object" relations: the relation between the "small other," objet petit $a$, and the "big Other," l'Autre. As Žižek long ago explained, "the most radical dimension of Lacanian theory" lies not in the "commonplace" that the Lacanian subject is divided/barred, but in "realizing that the big Other, the symbolic order itself, is also barré, crossed-out, by a fundamental impossibility, structured around an impossible/traumatic kernel, around a central lack," that the "structural network of relations" that comprises the symbolic order "can establish itself only in so far as it is embodied in a totally contingent material element, a little-bit-of-Real," the objet $a .{ }^{56}$ This, Žižek concludes, is the key to what Lacan called "traversing the fantasy," the realization not that the subject is forever separated from the object, but that "the object is separated from the Other itself, that the Other itself 'hasn't got it,' hasn't got the final answer - that is to say, is in itself blocked, desiring; that there is also a desire of the Other." 57 Traversing the fantasy thus cannot help but concern object-object relations insofar as it entails recognizing "how the ever-lacking object-cause of desire is in itself nothing but an objectivation, an embodiment of a certain lack; [...] how its fascinating presence is here just to mask the emptiness of the place it occupies, the emptiness which is exactly the lack in the Other - which makes the big Other [...] perforated, inconsistent." ${ }^{58}$ )

Having explained the "arche-transcendental" status of the objet $a$, Žižek, following "both Lacan and Hegel," proceeds to reframe the correlationist problematic, arguing that its answer lies not in grasping for an "objective reality which is independent of (its correlation to) subjectivity," but in grasping that "subjectivity is already inscribed into reality" in the form of the objet $a$. Žižek here anticipates our claim in the introduction to Subject Lessons that the In-itself is reached "not by tearing away subjective appearances and trying to isolate 'objective reality' as it is 'out there,' independently of the subject" - a move which only further mires us in the transcendental circle - but by attending to how the In-itself "inscribes itself precisely into the subjective excess, the subjective gap or inconsistency, that opens up a hole in reality" - the objet $a$ - rendering it "inconsistent, thwarted, non-all." 59 As Žižek further elaborates:

we cannot gain full neutral access to reality because we are part of it. The epistemological distortion of our access to reality is the result of our inclusion in it, not our distance from it. The objet $a$ is the splinter in the eye which distorts our clear perception of reality, and the agent of this distortion is desire (recall that the objet $a$ is the object-cause of desire). This

52 Žižek, The Sublime Object of Ideology, 75.

53 Žižek, The Plague of Fantasies, 117.

54 Žižek, The Indivisible Remainder, 164.

55 Žižek, The Sublime Object of Ideology, 178; The Indivisible Remainder, 164; The Ticklish Subject, 291.

56 Žižek, The Sublime Object of Ideology, 122, 183.

57 Ibid., 122.

58 Ibid., 195.

59 Sbriglia and Žižek, "Introduction,” 10. 
brings us to the unique "short-circuit between epistemology and ontology": the very epistemological failure (to reach reality) is an indication and effect of our being part of reality, our inclusion within it. ${ }^{60}$

Žižek's characterization of the objet $a$ as "the splinter in the eye" recalls the very example that Harman, in his critique of Krauss, rejects as an authentic escape from the correlationist circle: Lacan's floating sardine can as an instantiation of the objet $a$. As Lacan puts matters in this same episode, the objet $a$ (in its manifestation as gaze) is the point of "opacity," the "stain," or "spot," in the visual field "which is in no way mastered by me," but which, on the contrary, "grasps me, solicits me at every moment, and makes of the landscape something other than a landscape" - a stain which Lacan comes to identify with the subject itself. ${ }^{61}$ Sure enough, Žižek explicitly invokes this episode in his reply to Meillassoux, quoting what is arguably its most famous line as a means of encapsulating his point that the only way to access reality is through the subject's inscription into that reality in the form of the objet $a$, the excess that distorts it: "not only is the picture in my eye, but I am also in the picture." ${ }^{2}$ With this fundamental Lacanian lesson in mind, Žižek concludes that "what Meillassoux calls 'sickened' or 'failed' correlationism, far from being a halfhearted break-out from the correlationist constraint, is the key component of any true escape." ${ }^{63}$ Indeed, from the Lacano-Hegelian perspective, the tragic irony of Meillassoux's position is that it is his very "antitranscendentalism" that keeps his speculative materialism "trapped within the confines of the Kantiantranscendental opposition between reality the way it appears to us and the transcendent beyond of realityin-itself, independent of us." ${ }^{64}$ Hence Žižek's insistence that the way out of this bind is not "to think the Real outside of transcendental correlation, independently of the subject," but rather "to think the Real inside the subject, the hard core of the Real in the very heart of the subject, its ex-timate center." 65

Based on what we have seen, Harman's answer to such a claim would likely be that the objet $a$, however fond Lacanians are of dubbing it "a little piece of the Real," is not a real outside, for though "a perfectly fascinating psychoanalytic concept," the Lacanian Real is "merely a poor man's realism in philosophy." 66 Moreover, does not Žižek himself suggest as much when he says that we must "think the Real inside the subject," in its "very heart"? Does this not confirm Harman's suspicion that, at bottom, the Real is "just an immanent traumatic kernel in the subject," "an immanent trauma in consciousness itself?" 67 The key to properly responding to this question lies in Žižek's invocation of the Lacanian concept of "extimacy."

\section{Toward an extimate materialism}

In his seventh seminar, The Ethics of Psychoanalysis, Lacan coined the neologism "extimacy" (extimité) to characterize the relationship of the objet $a$ to the subject as one of "intimate exteriority." ${ }^{88}$ As Jamil Khader nicely summarizes it, Lacan deployed the term extimacy as a means of designating "a paradoxical mode of

60 Žižek, Less Than Nothing, 646.

61 Lacan, The Four Fundamental Concepts of Psychoanalysis, 96, 97, 96. As Lacan concludes, "[I]f I am anything in the picture, it is always in the form of [...] the stain, the spot” (97). This, of course, is the very line Žižek is invoking when, in the passage from The Parallax View of which Bryant is critical, he claims that " $[\mathrm{m}]$ aterialism means that the reality I see is never 'whole' not because a large part of it eludes me, but because it contains a stain, a blind spot, which indicates my inclusion in it." 62 Žižek, Less Than Nothing, 643. In what is arguably the most egregious of the many errors throughout his English translation of Seminar XI, Alan Sheridan interpolates an erroneous "not” into Lacan's original text ("Le tableau, certes, est dans mon oil. Mais moi, je suis dans le tableau"): "The picture, certainly, is in my eye. But I am not in the picture.” Lacan, Les Quatre Concepts Fondamentaux de la Psychanalyse, 89; The Four Fundamental Concepts of Psychoanalysis, 96.

63 Žižek, Less Than Nothing, 643.

64 Ibid.

65 Ibid., 644.

66 Harman, "The Battle of Objects and Subjects," 321; Art and Objects, 167.

67 Ibid., 320; Ibid.

68 Lacan, The Ethics of Psychoanalysis, 139. 
subjectivity in which binary oppositions such as inside and outside, intimate and external or foreign, are spliced and conjoined to engender a radical zone of indistinction that can be referred to as interiorexteriority." ${ }^{69}$ Though it has gone on to become one of the more central concepts in Lacanian theory, Lacan himself didn't use the term extimacy all that often; it would be left to collaborators and commentators like Jacques-Alain Miller and Žižek to pick it up and champion it. ${ }^{70}$ Lacan did, however, frequently speak of the subject's "ex-sistence," a paradigmatic example of which occurs at the outset of his "Seminar on "The Purloined Letter," when he speaks of "the ex-sistence (that is, of the eccentric place) in which we must necessarily locate the subject of the unconscious, if we are to take Freud's discovery seriously."71 Interestingly enough, as Bruce Fink explains in his translator's notes on the "Seminar," the term "exsistence" was first introduced into French by way of translations of Heidegger - arguably the most important thinker for Harman's $\mathrm{OOO}$ - to represent both the Greek "ekstasis" and the German "Ekstase," the root meaning of which in Greek is "standing outside of or standing apart from something," and which was generally used to connote "the 'removal' or 'displacement' of something," although "it also came to be applied to states of mind which we would now call "ecstatic." As Fink further explains, Lacan, drawing on Heidegger's play on both the term's root meaning as "standing outside" or "stepping outside oneself" and "its close connection in Greek with the root of the word for 'existence,"” regularly uses the term "ex-sistence" to "talk about 'an existence which stands apart from,' which insists as it were from the outside, to talk about something not included on the inside, something which, rather than being intimate, is 'extimate."'72

One of the few other instances in which Lacan explicitly uses the term "extimacy" is in his sixteenth seminar, D'un Autre à l'autre, where he again deploys it to designate a "conjoining of the intimate with the radically exterior." 73 In this instance, however, he links it to a series of "unorientable" objects, foremost among them the Möbius strip. ${ }^{74}$ As demonstrated by the illustration from Lacan's essay "Of Structure as an Inmixing of an Otherness Prerequisite to Any Subject Whatever" (Figure 1), the Möbius strip is an object which appears to be two-sided but which, when we trace around its directrix, we come to find is actually only one-sided. Lacan had already introduced the figure of the Möbius strip in his tenth seminar, Anxiety, wherein he illustrates its one-sidedness by describing an ant walking along its surface - an illustration of which by M.C. Escher would end up gracing the covers of both the French and English publications of the seminar (Figure 2). As Lacan explains, "An ant walking along one of the apparent faces [of the strip] will pass over to the other face without needing to go over the edge" because, in actuality, a Möbius strip is "a surface that has just one face." ${ }^{75}$ Properly speaking, there is no "edge" to a Möbius strip; there is merely a torsion or "twist" that makes what would otherwise be a two-faced object a single-faced one. ${ }^{76}$ One can thus never say whether an ant crawling along a Möbius strip is at any point on its "outside" or "inside" because a Möbius strip effectively has no outside or inside: the ant is at one and the same time both "inside" and "outside" the strip, which in turn means that it is really neither. In short, the ant's relation to the strip is an extimate one, a relationship of intimate exteriority, and it is this very same extimate relation, Lacan concludes, that "is involved when [objet] $a$ enters the world of the real." 77

69 Khader, “Concrete Universality and the End of Revolutionary Politics,” 145.

70 See, for instance, Miller's essay "Extimité," in which he explains that "the subject contains as the most intimate (intime) of its intimacy the extimacy of the Other" (75).

71 Lacan, Écrits, 6.

72 Fink in Lacan, Écrits, 767.

73 Lacan, D’un Autre à l'autre, 249. Lacan's original reads as follows: "Il est ici à une place que nous pouvons désigner du terme d'extime, conjoignant l'intime à la radicale extériorité."

74 Jacques-Alain Miller, in his editorial comments at the outset of lesson six of Seminar VII, had already noted the "difficulty of topographical representation" regarding the objet $a$ 's relation to the subject. As he explains, the objet $a$ "is at the center only in the sense that it is excluded [...]. [It] has to be posited as exterior, as the prehistoric Other that it is impossible to forget - the Other whose primacy of position Freud affirms in the form of something entfremdet [alienated], something strange to me, although it is at the heart of me.” Miller in Lacan, The Ethics of Psychoanalysis, 71.

75 Lacan, Anxiety, 96.

76 Ibid.

77 Ibid., 99. Lacan likewise says that "this is the $a[\ldots]$. The $a$ is put together like this" (97). 


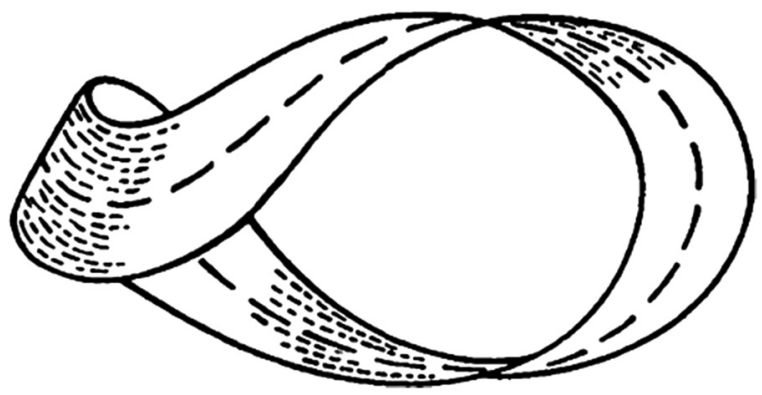

Figure 1: Möbius strip, from Jacques Lacan, "Of Structure as an Inmixing of an Otherness Prerequisite to Any Subject Whatever," 192.

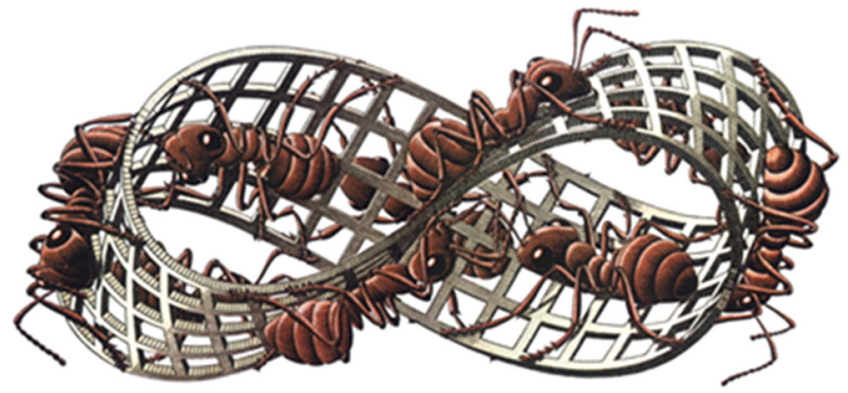

Figure 2: M.C. Escher, Mobius Strip II (1963).

There is considerable irony in the fact that although Harman devotes a sizeable portion of his response to Subject Lessons to engaging the chapter of it that most concerns the concept of extimacy, Molly Anne Rothenberg's “Twisting 'Flat Ontology': Harman’s ‘Allure’ and Lacan’s Extimate Cause,” he doesn’t once engage the concept of extimacy. ${ }^{78}$ To be fair, he comes close to doing so when, anticipating our response to the charge of idealism, he indulges in the following ventriloquization: "'For us it is not like Berkeley where everything is just an image, you see: there is a bone in the throat, a trauma in the subject, an Ansto $\beta$ that is sort of outside the mind even while not being really outside the mind"' - a position, he concludes, that amounts to wanting to have one's cake and eat it too. ${ }^{79}$ But as it turns out, it is Harman who "wants to have it both ways," so to speak, for his insistence on positioning the unconscious inside the subject when the "position of the unconscious" (to invoke the title of one of Lacan's most foundational écrits) is ultimately extimate, "ex-centric," ends up reifying a non-existent boundary between inside and outside that cannot but leave us trapped within the correlationist circle. ${ }^{80}$ In short, it is not Lacan himself that is guilty of idealism, but rather Harman's (mis)reading of him as a thinker for whom the unconscious is merely "a flaw in the jewel of consciousness.”

To further elaborate on this point, it is not entirely accurate to claim, as Harman (quoting Krauss) does, that Lacan "pictures the unconscious [...] as inside consciousness, undermining it from within." 81 To quote

78 To be precise, Harman does mention extimacy in passing when he notes that Rothenberg's argument hinges on the claim that "Lacan's notion of 'extimate cause”" better addresses the aims of Harman's own concept of “allure.” Harman doesn't, however, at all engage the concept of extimacy itself. Harman, "The Battle of Objects and Subjects," 327.

79 Harman, "The Battle of Objects and Subjects," 320.

80 My use of "ex-centric" is a nod to the aforementioned passage from the "Seminar on "The Purloined Letter" in which Lacan explains that by "ex-sistence" he means "the eccentric place" (la place excentrique) of the subject of the unconscious; however, he likewise speaks of the subject's "radical eccentricity with respect to itself" (l'excentricité radicale de soi à lui-même) - or, as Alan Sheridan translates it, the subject's "radical ex-centricity to itself" - in his essay "The Instance of the Letter in the Unconscious.” Lacan, Écrits, 435; Écrits: A Selection, 130.

81 Harman, Art and Objects, 129. 
what Lacan himself says of the position of the unconscious (this from Seminar XI, the very same seminar in which he introduces his theory of the gaze as objet a): "I say somewhere that the unconscious is the discourse of the Other. Now, the discourse of the Other that is to be realized, that of the unconscious, [...] is outside." ${ }^{2}$ Nodding to this very passage, Jacques-Alain Miller argues that Lacan's point can be "expressed with a single word: 'extimacy,"” for extimacy is precisely "what Lacan is commenting on when he speaks of the unconscious as discourse of the Other, of this Other who, more intimate than my intimacy, stirs me." As Miller concludes, "If we use the term 'extimacy' in this way, we can consequently make it be equivalent to the unconscious itself." ${ }^{83}$ Lacan insists that the unconscious is outside because its intimacy with respect to the subject is so in excess of the intimate that it can only be described as extimate, something that ex-sists, that is ex-centric. And that this excess inscribes itself in reality in the form of the objet $a$ - the little piece of the Real whose "phenomenalization," as Hegel might put it, effectuates a rend in this very reality, rendering it non-all - is the very "thing" that makes dialectical materialism a materialism. ${ }^{84}$

It is also what makes it a non-idealism, for the co-relation between subject and objet $a$ is, as those in the Ljubljana camp like to put it, a "relation of non-relation." When it comes to the relation between subject and objet $a$, we are dealing not with two discrete entities participating in an "intersubjective" exchange of gazes that results in a "mutual recognition" between the two - which, incidentally, is the same misunderstanding of the dialectic perpetuated by those who read Hegel as a philosopher of "mutual recognition." For Lacan (as for Hegel), the (non-)relation between subject and objet $a$ is one not of recognition but misrecognition (méconnaissance). As Žižek and I explain in our introduction to Subject Lessons, subject and objet $a$ "can never encounter each other in a direct opposition or mirroring, but are instead like the two sides of the same spot on a Möbius strip." ${ }^{55}$ This is the function of the lozenge/poinçon $(\diamond)$ in Lacan's formulaic rendering of the relationship between the (barred) subject and the objet $a$ as " $\$ \diamond a$." As Fink explains, the lozenge stands just as much for the "disjunction" between subject and objet $a$ as their "conjunction." " 60 thus invoke another line of Lacan's that Harman is critical of in his response to Subject Lessons, "the reciprocity between the subject and object $a$ is total" because subject and objet $a$ are not two discrete, interrelating objects, but are, rather, "impossibly" one and the same object. ${ }^{87}$ Hence our insistence that "what new materialists and realists understand as 'subject' simply fails to meet the criteria of the subject." 88

To put a finer point on this claim, let us consider Lacan's theory of the gaze as anamorphosis - which, like the floating sardine can anecdote, is found in Seminar XI. The typical understanding of anamorphosis is that of a "subject" whose desire causes it to "look awry" at an object, thereby distorting and, subsequently, elevating/sublimating it to the position of objet $a$. But "anamorphosis" for Lacan names less the process whereby the subject creates/confronts the sublime object and more the phenomenon whereby the "human being" confronts that which is in excess of itself, that "vital dehiscence" which is at one and the

82 Lacan, The Four Fundamental Concepts of Psychoanalysis, 131.

83 Miller, "Extimité," 77.

84 I would be remiss if, having nodded to Hegel's Phenomenology of Spirit, I didn't here invoke the famous line from its preface that "everything turns on grasping and expressing the True, not only as Substance, but equally as Subject," a line which means, as Adrian Johnston nicely glosses it, that "material being, as incomplete and inconsistent, contains within itself the potentials for the creative genesis of modes of subjectivity exceeding this same ontological foundation." In short, "subject" is the name Hegel gives to the rift in material being, that which undermines substance's substantiality, its identity (i.e., its "completeness" and "consistency"). Hegel, Phenomenology of Spirit, 10; Johnston, Adventures in Transcendental Materialism, 121-2.

85 Sbriglia and Žižek, "Introduction," 26-7n44.

86 Fink in Lacan, Écrits, 542n17.

87 Lacan, Encore, 114. This line, which Žižek and I quote in our introduction to Subject Lessons (14), is one of the lines that Harman, in his response to Subject Lessons (321), is most critical of.

88 Sbriglia and Žižek, "Introduction,” 14-5. Interestingly enough, Bryant makes this very point in his response to Žižek’s critique of his book The Democracy of Objects on his blog, Larval Subjects. Insisting that he is actually "not in disagreement with Žižek about the status of the (Cartesian) subject" as a "void or emptiness," a figure "evacuat[ed] of all substantial content (identity)," Bryant goes on to explain that, "When, in so much contemporary theory, we encounter endless critiques of 'the subject,' what we're truly encountering is not a critique of the subject, but rather of the ego or the thesis that identity is a substantial property of the subject.” Though I find such a position somewhat difficult to square with his own object-oriented ontology, I cannot but completely agree with Bryant here. 


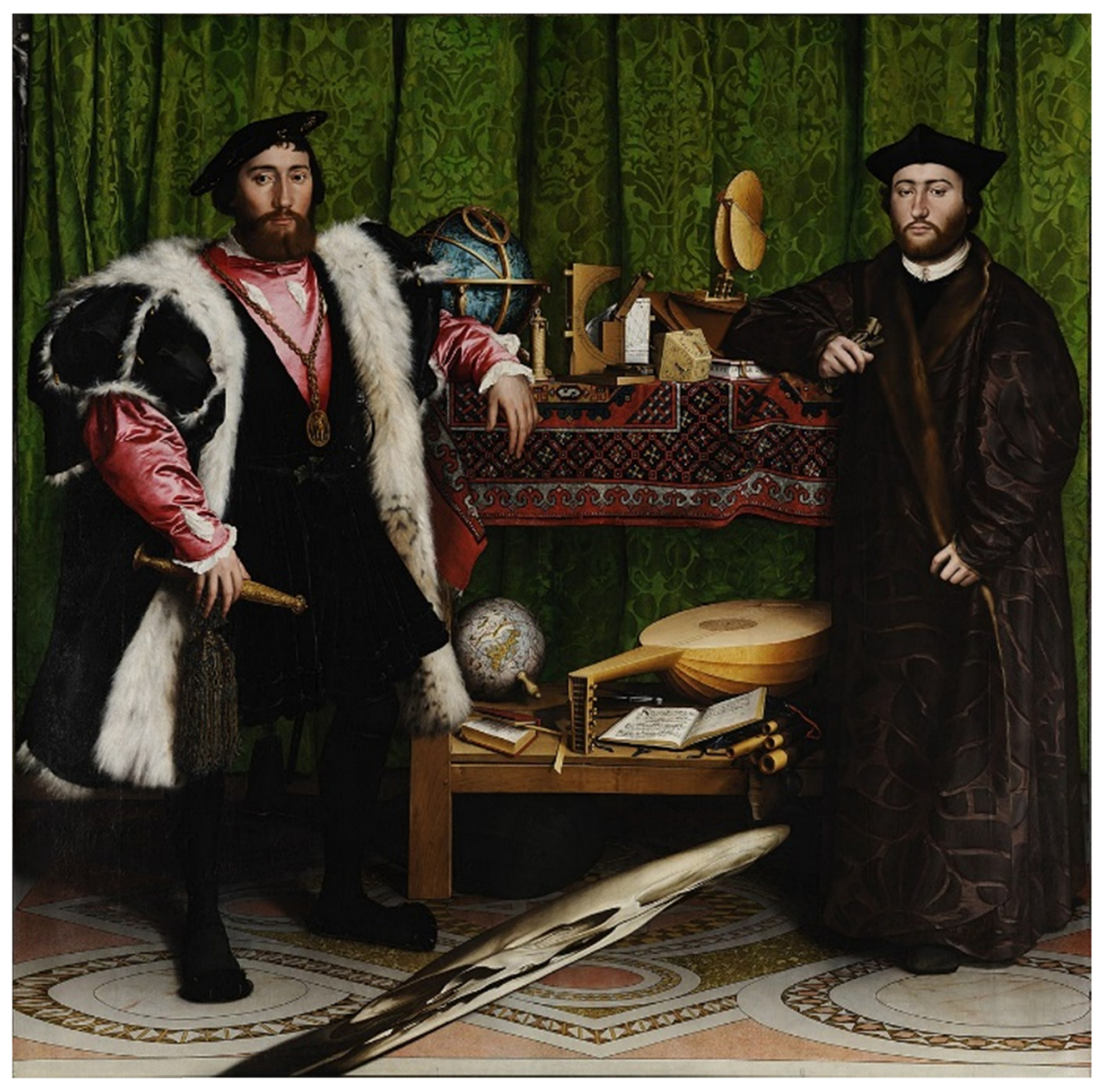

Figure 3: Hans Holbein, The Ambassadors (1533).

same time "constitutive of man" (to recall an aforementioned line of Lacan's) and which "renders man as such "nature sick unto death"” (to invoke a line from our introduction to Subject Lessons): the phenomenon of subjectivity. This is the real lesson of Lacan's discussion of the famous Hans Holbein painting, The Ambassadors (Figure 3), his primary example of anamorphosis. It is not the case that "subject" refers to the person viewing the painting, while objet $a$ refers to the anamorphic skull lying at the bottom center of the canvas. Rather, the anamorphic skull, as objet $a$, is itself the subject: they are one and the same. ${ }^{89}$ Thus, when Lacan says "not only is the picture in my eye, but I am also in the picture," his point is not simply, as Harman interprets it, that "the world looks at me just as I look at it," as though he is merely talking about a reciprocal, dyadic relation between subject (as viewer) and objet $a$. To grasp the true import behind Lacan's claim, we must distinguish between the phenomenal "my"/"me," the person viewing the picture, and the (objet) a priori "I," the "stain," the "blind spot," the "bone in the throat," that embodies, that phenomenalizes, the alienated, extimate core of subjectivity. ${ }^{90}$

And this returns us to Bryant's critique of Žižek's claim that “ $[\mathrm{m}]$ aterialism means that the reality I see is never 'whole' - not because a large part of it eludes me, but because it contains a stain, a blind spot, which indicates my inclusion in it," a stain/blind spot that renders material reality "non-all." I cannot but agree

89 Hence Zupančič's insistence in her chapter of Subject Lessons, “Ontology and the Death Drive," that if, as OOO argues, the subject were merely one object among a "democracy of objects" (a phrase of Bryant's, of course), then "there would be no need for the concept of the subject (in the strong philosophical and psychoanalytic sense); the term 'person' (or 'human being') would suffice" (160). Failure to distinguish between "subject” and "person"/“human being” is a key feature of Harman's response to Subject Lessons, wherein he continually refers to the "human subject."

90 This is why it is simply incorrect for Harman to claim that Žižek "eliminat[es] the object as anything more than a stain or spot in the subject." The spot is not "in" the subject; rather, it is the subject itself in its extimate embodiment as objet a. Harman, “Žižek’s Parallax,” 33. 
with Bryant that this is indeed a "peculiar proposition.” It is the proposition, in fact, of a "weird," extimate materialism - "weird" insofar as, like Harman's "weird realism," it is primarily concerned with reality's "incommensurability with any attempt to represent or measure it." of "weird realism" double as a very definition of the Lacanian Real as the remainder or leftover resultant from the incommensurability of reality and every attempt to represent it, to fully integrate it into the symbolic order? And yet, a crucial difference nonetheless persists between the two positions. For whereas Harman insists that the way to access this weird, excessive reality is to flatten the ontological plane and attend to object-object relations, following Hegel and Lacan this excess can only be accessed by attending to the "weird," extimate object that, in giving body to the subject's "out-of-jointness," curves or biases the ontological plane, "disorienting" reality, rendering it much like a Möbius strip - or an anamorphic skull.92

Hence Alenka Zupančič's claim that "[i]f there is an ontology that follows from psychoanalytic (Lacanian) theory, this can only be an ontology as 'disoriented' by what he calls the object $a$ " - in short, an "object-disoriented ontology." ${ }^{93}$ Such an object-disoriented ontology - or, as Joan Copjec has dubbed it, an "object $a$ ontology" - would, as Lacan himself knew, more accurately be characterized as a "para-ontology" insofar as the objet $a$, the inscription of the subject into reality, is "not of the order of being" but is, rather, being's "inherent impasse," the cut or crack that "curves and determines" being's "appear[ance]" by "haunt[ing it] from within, in-form[ing] it,"94 leaving it "beside itself," "ex-static." To strike a Derridean note, we might say that the subject is "hauntological," a "ghost in the machine" of being. To strike - and end on - a more Ljubljanian note, we might say that the subject is the "short circuit" in being. This, above all else, is why we so "dogmatically" insist upon the subject's necessity to any future materialism whatsoever.

Conflict of interest: Authors state no conflict of interest.

\section{References}

Badiou, Alain. “Lacan and the Pre-Socratics.” In Lacan: The Silent Partners, edited by Slavoj Žižek, 7-16. New York: Verso, 2006.

Bennett, Jane. "Systems and Things: On Vital Materialism and Object-Oriented Ontology." In The Nonhuman Turn, edited by Richard Grusin, 223-39. Minneapolis: University of Minnesota Press, 2015.

Boswell, James. Life of Johnson, edited by R. W. Chapman. New York: Oxford University Press, 1990.

Bryant, Levi R. The Democracy of Objects. Ann Arbor, MI: Open Humanities Press, 2011.

Bryant, Levi R. Onto-Cartography: An Ontology of Machines and Media. Edinburgh: Edinburgh University Press, 2014.

Bryant, Levi R. “Žižek on The Democracy of Objects." Larval Subjects, 21 November, 2016. https://larvalsubjects.wordpress. com/2016/11/21/zizek-on-the-democracy-of-objects-2/.

Cole, Andrew. "The Nature of Dialectical Materialism in Hegel and Marx." In Subject Lessons, edited by R. Sbriglia and S. Žižek, 82-101. Evanston, IL: Northwestern University Press, 2020.

91 Harman, Weird Realism, 51.

92 Hence Rothenberg's branding of this "excessive subject” throughout her book of the same name, The Excessive Subject, the "Möbius subject."

93 Zupančič, What IS Sex?, 24.

94 Ibid., 22, 24; Copjec, email correspondence. In claiming that Lacanian ontology is a "para-ontology,” I am referencing Lacan's claim in Seminar XX, Encore, that "we must get used to substituting the 'para-being' - the being 'para,' being beside for the being that would take flight” (44). Zupančič, in her What IS Sex?, has her own compelling reading of this passage, one that centers on the drive's repetition of the crack or gap, the "non-being," at the heart of being (133-4). Viewed through the lens of extimacy, however, I would like to propose a somewhat different reading of this passage. I would like to suggest that we can read Lacan's "para," or "beside," as referring not to the subject's linear orientation with regard to the order of being (that is, "beside" as in being "next to" or "in juxtaposition with"), but rather to the fundamental disorientation, the fundamental unorientability, of the subject's being (that is, "beside" as in being "beside oneself," like Oedipus, for instance, is "beside himself" upon learning that he has, in fact, killed his father and married his mother). 
DeLanda, Manuel. Intensive Science and Virtual Philosophy. New York: Continuum, 2002.

DeLanda, Manuel and Graham Harman. The Rise of Realism. Malden, MA: Polity Press, 2017.

Dolar, Mladen. "Tyche, clinamen, den." Continental Philosophy Review 46:2 (2013), 223-39.

Dolar, Mladen. "What's the Matter? On Matter and Related Matters." In Subject Lessons, edited by R. Sbriglia and S. Žižek, 31-49, Evanston, IL: Northwestern University Press, 2020.

Gorelick, Nathan. "Why Sex Is Special: Psychoanalysis against New Materialism.” In Subject Lessons, edited by R. Sbriglia and

S. Žižek, 171-89. Evanston, IL: Northwestern University Press, 2020.

Harman, Graham. Towards Speculative Realism: Essays and Lectures. Washington, D.C.: Zero Books, 2010.

Harman, Graham. Quentin Meillassoux: Philosophy in the Making. Edinburgh: Edinburgh University Press, 2011.

Harman, Graham. Weird Realism: Lovecraft and Philosophy. Washington, D.C.: Zero Books, 2012.

Harman, Graham. "Foreword.” In Manifesto of New Realism, by Maurizio Ferraris, trans. Sarah De Sanctis, ix-xii. Albany: State

University of New York Press, 2014.

Harman, Graham. Immaterialism: Objects and Social Theory. Malden, MA: Polity, 2016.

Harman, Graham. Object-Oriented Ontology: A New Theory of Everything. New York: Pelican, 2017.

Harman, Graham. “The Battle of Objects and Subjects: Concerning Sbriglia and Žižek’s Subject Lessons Anthology.” Open

Philosophy 3 (2020), 314-34.

Harman, Graham. Art and Objects. Medford, MA: Polity, 2020.

Harman, Graham. “Žižek's Parallax, or The Inherent Stupidity of All Philosophical Positions.” In Parallax: The Dialectics of Mind and World, edited by Dominik Finkelde, Slavoj Žižek, and Christoph Menke, 27-38. New York: Bloomsbury, 2021.

Hegel, G. W. F. Phenomenology of Spirit, trans. A. V. Miller. New York: Oxford University Press, 1977.

Hegel, G. W. F. Lectures on the History of Philosophy. Vol. 1, Greek Philosophy to Plato, trans. E. S. Haldane. Lincoln: University of Nebraska Press, 1995.

Johnston, Adrian. Adventures in Transcendental Materialism: Dialogues with Contemporary Thinkers. Edinburgh: Edinburgh University Press, 2014.

Johnston, Adrian. Prolegomena to Any Future Materialism. Vol. 2, A Weak Nature Alone. Evanston, IL: Northwestern University Press, 2019.

Johnston, Adrian. "Fear of Science: Transcendental Materialism and Its Discontents." In Subject Lessons, edited by R. Sbriglia and S. Žižek, 125-41, Evanston, IL: Northwestern University Press, 2020.

Khader, Jamil. "Concrete Universality and the End of Revolutionary Politics: A Žižekian Approach to Postcolonial Women's Writings." In Everything You Always Wanted to Know about Literature but Were Afraid to Ask Žižek, edited by Russell Sbriglia, 137-68. Durham: Duke University Press, 2017.

Krauss, Rosalind E. The Optical Unconscious. Cambridge, MA: MIT Press, 1993.

Lacan, Jacques. Écrits. Paris: Éditions du Seuil, 1966.

Lacan, Jacques. "Of Structure as an Inmixing of an Otherness Prerequisite to Any Subject Whatever." In The Structuralist Controversy: The Language of Criticism and the Sciences of Man, edited by Richard Macksey and Eugenio Donato, 186-200. Baltimore: Johns Hopkins University Press, 1970.

Lacan, Jacques. Le Séminaire de Jacques Lacan, Livre XI: Les Quatre Concepts Fondamentaux de la Psychanalyse, 1964, edited by Jacques-Alain Miller. Paris: Éditions du Seuil, 1973.

Lacan, Jacques. The Seminar of Jacques Lacan, Book VII: The Ethics of Psychoanalysis, 1959-1960, edited by Jacques-Alain Miller, trans. Dennis Porter. New York: Norton, 1992.

Lacan, Jacques. The Seminar of Jacques Lacan, Book XI: The Four Fundamental Concepts of Psychoanalysis, 1964, edited by Jacques-Alain Miller, trans. Alan Sheridan. New York: Norton, 1998.

Lacan, Jacques. The Seminar of Jacques Lacan, Book XX: Encore: On Feminine Sexuality, the Limits of Love and Knowledge, 1972-1973, edited by Jacques-Alain Miller, trans. Bruce Fink. New York: Norton, 1998.

Lacan, Jacques. Écrits: The First Complete Edition in English, trans. Bruce Fink. New York: Norton, 2006.

Lacan, Jacques. Le Séminaire de Jacques Lacan, Livre XVI: D'un Autre à l'autre, 1968-1969, edited by Jacques-Alain Miller. Paris: Éditions du Seuil, 2006.

Lacan, Jacques. Le Séminaire de Jacques Lacan, Livre XVIII: D'un discours qui ne serait pas du semblant, 1971, edited by JacquesAlain Miller. Paris: Éditions du Seuil, 2006.

Lacan, Jacques. The Seminar of Jacques Lacan, Book X: Anxiety, edited by Jacques-Alain Miller, trans. A. R. Price. Malden, MA: Polity, 2014.

Lenin, V. I. Collected Works. Vol. 38, Philosophical Notebooks. Moscow: Foreign Languages Press, 1961.

Marx, Karl and Friedrich Engels. The Marx-Engels Reader, 2nd ed., edited by Robert C. Tucker. New York: Norton, 1978.

McGowan, Todd. “Objects After Subjects: Hegel’s Broken Ontology.” In Subject Lessons, edited by R. Sbriglia and S. Žižek, 68-81, Evanston, IL: Northwestern University Press, 2020.

Meillassoux, Quentin. After Finitude: An Essay on the Necessity of Contingency, trans. Ray Brassier. New York: Continuum, 2008. Meillassoux, Quentin. Time Without Becoming, edited by Anna Longo. Milan: Mimesis International, 2014.

Miller, Jacques-Alain. “Extimité." In Lacanian Theory of Discourse: Subject, Structure, and Society, edited by Mark Bracher, Marshall W. Alcorn, Jr., Ronald J. Corthell, and Françoise Massardier-Kenney, 74-87. New York: NYU Press, 1994.

Rothenberg, Molly Anne. The Excessive Subject: A New Theory of Social Change. Malden, MA: Polity, 2010. 
Rothenberg, Molly Anne. “Twisting ‘Flat Ontology’: Harman’s ‘Allure’ and Lacan’s Extimate Cause.” In Subject Lessons, edited by R. Sbriglia and S. Žižek, 190-208, Evanston, IL: Northwestern University Press, 2020.

Sbriglia, Russell and Slavoj Žižek. “Introduction: Subject Matters.” In Subject Lessons, edited by R. Sbriglia and S. Žižek, 3-28, Evanston, IL: Northwestern University Press, 2020.

Sbriglia, Russell and Slavoj Žižek, eds. Subject Lessons: Hegel, Lacan, and the Future of Materialism. Evanston, IL: Northwestern University Press, 2020.

Sheldon, Rebekah. "Form/Matter/Chora: Object-Oriented Ontology and Feminist New Materialism." In The Nonhuman Turn, edited by Richard Grusin, 193-222. Minneapolis: University of Minnesota Press, 2015.

Zedong, Mao. “Annotations to Li Da's Outline of Sociology.” In Mao's Road to Power: Revolutionary Writings, 1912-1949; Volume VI: The New Stage: August 1937-1938, edited by Stuart Schram, 808-26. New York: Routledge, 2015.

Žižek, Slavoj. The Sublime Object of Ideology. New York: Verso, 1989.

Žižek, Slavoj. Tarrying with the Negative: Kant, Hegel, and the Critique of Ideology. Durham, NC: Duke University Press, 1993. Žižek, Slavoj. The Indivisible Remainder: An Essay on Schelling and Related Matters. New York: Verso, 1996.

Žižek, Slavoj. The Plague of Fantasies. New York: Verso, 1997.

Žižek, Slavoj. The Ticklish Subject: The Absent Centre of Political Ontology. New York: Verso, 1999.

Žižek, Slavoj. The Parallax View. Cambridge, MA: MIT Press, 2006.

Žižek, Slavoj. Less Than Nothing: Hegel and the Shadow of Dialectical Materialism. New York: Verso, 2012.

Žižek, Slavoj. Absolute Recoil: Towards a New Foundation of Dialectical Materialism. New York: Verso, 2014.

Žižek, Slavoj. Disparities. New York: Bloomsbury, 2016.

Žižek, Slavoj. “Marx Reads Object-Oriented Ontology.” In Reading Marx, by Slavoj Žižek, Frank Ruda, and Agon Hamza, 17-61. Medford, MA: Polity, 2018.

Žižek, Slavoj and Glyn Daly. Conversations with Žižek. Malden, MA: Polity, 2003.

Zupančič, Alenka. What IS Sex? Cambridge, MA: MIT Press, 2017.

Zupančič, Alenka. “Ontology and the Death Drive: Lacan and Deleuze.” In Subject Lessons, edited by R. Sbriglia and S. Žižek, 142-70, Evanston, IL: Northwestern University Press, 2020. 